\title{
STATE ADMINISTRATIVE LEGAL REVIEW ON THE BILL OF RETRACTION LAW OF CORRUPTED ASSETS IN ERADICATION EFFORT OF CORRUPTION IN INDONESIA
}

\author{
Dian Puji Simatupang ${ }^{1}$
}

\begin{abstract}
Since eradicating corruption having been continously encouraged by late governments - and until now - , there would not be less important as to retracting the corrupted assets. There are many aspects to be considered in doing such action, such as manifesting the legal aspects of administrative law, and so other applied national regulations. By these regulations, such as Law No. 7 of 2006 on Ratification of United Nations Convention against Corruption, 2003 (Konvensi Perserikatan Bangsa Bangsa Anti-Korupsi, 2003), Law Number 25 of 2003 On Amendment to Law Number 15 of 2002 on Money Laundering, Act 30 of 2002 on Corruption Eradication Commission, Law Number 20 Year 2001 regarding Amendment to Law Number 31 Year 1999 on the Eradication of Corruption, and Government Regulation Number 65 of 1999 on Implementation Procedures for Examination of State Property, retraction the corrupted assets should be define in order to get known about eradicating corruption.

Another issue that urgently to be defined, as it also become main subject of retracting assets, is the asset itself. Indeed, as the asset which become mainly discussed about is State assets. So, it would be very necessary to clearly have a distinction between State responsibility and that of irresponsibility of the State, in order to settle down, as an after effect, many interpretations.
\end{abstract}

Keywords: corruption, administrative law, assets

\section{Introduction}

Eradicating corruption in Indonesia has been continually a heading for each period from our first President government, Soekarno, until now. The most important thing of corruption law enforcement is that of retracting the corrupted assets. By retracting the corrupted assets means in the public administration legal analysis in this study is restricted to the utilization of money beyond the need and intended purpose of the state's funds. This means the government spending is not used in accordance with the intended purpose of state money which ultimately affects the state financial position which consequently meets the legal requirement of state's losses which is one of the corruption crime elements.

\footnotetext{
${ }^{1}$ Lecturer of Administrative Law, Faculty of Law, University of Indonesia. Obtained Bachelor of Law (S.H.) from University of Indonesia (1999), Master of Law (M.H.) from University of Indonesia (2004), and Doctor of Law (Dr.) from University of Indonesia (2011). The author can be contacted at dian.puji@ ui.ac.id. Lecturer at Faculty of Law, University of Indonesia.
} 


\section{Legal aspects of State Administrative Law on the Seizure of the corrupted assets}

By seizure of the corrupted assets means in the public administration legal analysis in this study is restricted to the utilization of money beyond the need and intended purpose of the state's funds. This means the government spending is not used in accordance with the intended purpose of state money which ultimately affects the state financial position which consequently meets the legal requirement of state losses which is one of the corruption crime elements.

According to Law No. 1 of 2004, meant by state's / regional loss is, "loss of money, securities and goods, in real and definite amount as a result of unlawful act, either intentionally or negligently." The purpose of this unlawful act is an act of corruption, manipulative, and embezzlement. Meanwhile, the negligent act which causes unintentional errors in book keeping or accounting and financial calculations.

The presence of the state's loss aspect of corruption in the state's financial management is likely to occur due to a lack of state financial control to meet the accountability aspect. The point is that supervision is not based on accountability plans, goals, objects, and aspects of legislation in the use of state finances. One of other causes of the state's loss is the lack of clarity about the state financial audit procedures that will pass the examination object. This occurs with regards to the conditions where auditor institution having too vast span of control upon the audit objects.

\section{Anti-Corruption Regulation in Indonesia}

Eradicating corruption in Indonesia has been continually a heading for each period from the Soekarno government until now. It had been a long history of several anti-corruption arrangements. The most important thing of corruption law enforcement is that of retracting the corrupted assets. So far, this is still a very hot issue discussed related to formal and material matters. Legislation and several Law are as follows:

\section{A. Law No. 7 of 2006 on Ratification of United Nations Convention against Corruption, 2003 (Konvensi Perserikatan Bangsa Bangsa Anti-Korupsi, 2003)}

This law is a law born in Indonesian people's needs in fighting off the corruption. Ratification of this convention is a further commitment from the Government of Indonesia in combating corruption. Ratification of this convention has significant roles for Indonesia, especially related to international politics. Government of Indonesia has been able to demonstrate a commitment not only of national interest as such, but on the broader level in combating corruption as well. In addition to laying the international arena, the ratification has also become absolutely necessary when the Indonesian people are making the fight against corruption a major commitment.

Corruption is considered important in its role in the global sphere since 2000 in which the UN General Assembly 55th Session through Resolution No. 55/61 dated December 6, 2000 was on the view that corruption requires 
formulation of international instruments. Moreover, in the ratification of this convention was also considering a few things, as follows:

1. To enhance international cooperation in tracing, freezing, seizing and returning the assets of the proceeds of crime which are stationed abroad.

2. Enhance international cooperation in actualizing good governance.

3. Enhance international cooperation in the implementation of extradition treaties, mutual legal assistance, transfer of prisoners, the transfer of criminal proceedings, and law enforcement cooperation.

4. Encourage technical cooperation and information exchange in the prevention and eradication of corruption under the umbrella of economic development cooperation and technical assistance within the scope of bilateral, regional, and multilateral arrangements.

5. Harmonization of national legislation in the prevention and eradication of corruption in accordance with this Convention.

Under this Convention, in Article 1 of the Statement of Purpose is said that the starting point of the formation of this convention is about the return on assets. It is said expressively in Article 1 paragraph (2) that the purpose of this Convention is to promote, facilitate and support international cooperation and technical assistance in the prevention and eradication of corruption, including asset recovery. Return on assets is the main thing of corruption crime eradication. Therefore it is necessary to see the definition or understanding of the asset at the convention of which type of the corruptor wealth of should be included in the category of assets and how the process of return on assets considering the provisions of Law No. 7 of 2006 on Ratification of UN Convention Against Corruption.

Arrangements in Article 2 on the Use of Terms related to assets are stipulated in point $d$ about description of wealth. Mentioned that wealth in this Convention means "assets of any kind, whether corporeal or incorporeal, mobile or immobile, tangible or intangible, and legal documents or instruments evidencing the right to or interest in such assets." the meaning of wealth is then added by the settings in Article 2 letter e describing about "the proceeds of crime". It is said that meant by the proceeds of crime from the criminal acts of corruption is "all wealth derived from or obtained, directly or indirectly, through the implementation of a crime." Given the scope of the above conditions several points could be taken extracted off the meaning of assets based on this Convention:

1. Assets which could of corruption act could be of any shape whether corporeal or incorporeal which could be moveable or static asset which unit could be as well tangible or intangible.

2. In addition to the foregoing, the assets could also be legal documents or instruments evidencing over something or interest in such assets.

3. The assets acquired directly or indirectly, either obtained or derived from the execution of a crime.

4. Material proof of corrupted assets is widely spread, not necessarily in the form of objects or goods, and not just in the form of money or any other subjects that are categorized as cash. 
Which could be further inspired by the Convention is about setting the freezing, seizure and forfeiture. As referred from primary aim of this paper is to identify the definition of assets and in search for the perfect system of how the implementation of the asset returns itself. Arrangements regarding the freezing, seizure and confiscation of corruption proceeds of crime in general are set in the middle of this Convention. These settings are included in the section 31 which is approximately as follows:

\section{Article 31 - Freezing, Seizure and Confiscation}

(1) Each State Party shall take, as long as is possible within its domestic legal system, such measures as may be necessary to enable confiscation of:

a. Proceeds of crime derived from offenses established in compliance with this Convention or property which value indicates the value of such proceeds;

b. Property, equipment or other instrumentalities used in or intended for use in offenses established in accordance with this Convention.

(2) Each State Party shall take such measures as may be necessary to enable the identification, tracing, freezing or seizure of any item referred to in paragraph (1) of this article with the aim of deprivation on time.

(3) Each State Party shall adopt, in accordance with domestic law, legislative and other measures as may be necessary to regulate the administration by the competent authorities of frozen, seized or confiscated property referred to in paragraph (1) and (2) of this Article.

(4) If such proceeds of crime have been transformed or converted, in part or in full, into other property, such property shall be liable to the measures referred to in this Article, in lieu of such proceeds.

(5) If such proceeds of crime have been confused by the wealth derived from legitimate sources, such property shall, without disregarding any powers relating to freezing or seizure, be liable to confiscation up to the assessed value of the mixed proceeds.

(6) Income or other benefits derived from the proceeds of crime, from property into which proceeds of crime have been transformed or converted or from property which proceeds of crime have been confused with must also be liable referring to this Article, the same way and as long as all are treated the same as the proceeds of crime.

(7) For the purposes of this Article, and Article 55 of this Convention, each State Party shall empower its courts or competent authorities to order that records of bank, financial or commercial institutions be made available or seized. Under the provisions of this Article, State Parties may not refuse to act by reason of bank secrecy.

(8) States Parties may consider the possibility of requiring that an offender demonstrate the lawful origin of the proceeds of crime or other property alleged to be liable to seizure, as long as such requirements in accordance with fundamental principles of their domestic law and the nature of the court process and other processes. 
(9) The provisions of this Article should not be interpreted as ignoring the rights of third parties acting in good faith.

(10) None of the provisions of this Article shall affect the principle that the measures referred to in the Article is interpreted and implemented in accordance with and under the provisions of national law of a State Party.

Arrangements in Article 31 of this Convention does explicitly have set about the sustainability of an asset or property that is the result of corruption, including in it about how the provisions concerning the form of assets even if it is used. Investigation on the wealth of corruption crimes outcomes referring to the Convention also describes the form of wealth that has been transformed as if the corruption or the use of public finance can be made seizure and confiscation of cars or other properties purchased using the state finances. Therefore, with reference in this Convention it has been firmly set regarding the form of wealth that is intended in the act of corruption.

Another thing obtained from the setting in the Law on the ratification of this Convention is that concerning the returns of assets was taken care of. Return on assets is also referred to and dealt with in this Act namely in section 57 which is covered in a special chapter on asset recovery. The settings are as follows:

\section{Article 57 - Refunds and Delivery of Assets}

(1) Property confiscated by a State Party under Article 31 or Article 55 of this Convention shall be submitted, including a return to its prior legitimate owners, pursuant to paragraph (3) of this Article, the State Party in accordance with the provisions of this Convention and domestic law.

(2) Each State Party shall adopt such legislative and other measures, in accordance with the principles of its domestic law, as may be necessary to enable competent authorities to return confiscated property, when the act involves a request made by another State Party, accordance with this Convention, taking into account the rights of third parties acting in good faith.

(3) In accordance with Article 46 and Article 55 of this Convention and paragraph (1) and paragraph (2) of this Article, the requested State Party shall:

a. In the case of embezzlement of public funds or laundering of embezzled funds referred to Article 17 and Article 23 of this Convention, when confiscation carried out in accordance with Article 55 and on the basis of a final judgment in the requesting State Party, a requirement which may be waived by the requested State parties, return the confiscated property to the requesting State Party;

$b$. In the case of proceeds of any other offense covered by this Convention, when confiscation was executed in accordance with Article 55 of this Convention and on the basis of a final judgment in the requesting State Party, a requirement which may be waived by the requested 
State Party, return the property that deprived the requesting State Party, if the requesting State Party determine the previous lawfully ownership of their property to the requested State Party or if the requested State Party declared a loss to the requesting State Party as a basis for returning the confiscated property;

c. In all other cases, give priority consideration to returning confiscated property to the requesting State Party, returning such property to its prior legitimate owners or compensating the loss in favor of the crime victims.

(4) If appropriate, unless States Parties decides otherwise, the requested State Party can reduce expenses imposed in investigations, prosecutions, or court proceedings leading to the return or transfer of property seized pursuant to this article.

(5) Where appropriate, States Parties may also give special considerations to make agreements or arrangements mutually acceptable, on a case by case basis, for the final delivery of the seized property.

In addition to the regulating the asset return process and cooperation mechanisms, within the provisions of this Convention, it is further stated that the implementation under the provisions of domestic law in Indonesia under this Convention is not yet clear regarding the party involved in this convention. Thus, if there is corruption in certain state institutions and the implementation of the seizure and confiscation of the money has been made, the basic issue is whether the spoils of the crime are then immediately returned to the institution concerned. On the basis of this Convention provisions, it is not as such set but in reference to the Article 35 - Compensation for Losses:

"Each State Party shall take such measures as may be necessary, in accordance with the principles of domestic law, to ensure that entities or persons who suffered from losses, as a result of an act of corruption, have the right to initiate legal proceedings against those responsible for that damage in order to obtain compensation thereof."

Therefore, the arrangement of the affected institutions are borne by the state, noticeably that result from the seizure of assets then belong to the wealth of the country in general, not directly to the wealth of the country at any post of a definite institution.

\section{B. Law Number 25 of 2003 On Amendment to Law Number 15 of 2002 on Money Laundering.}

This law regulates specifically the money laundering criminal acts. Cases observed in the regulation of money laundering are about how the money laundering of corruption proceeds is undertaken or the proceeding of the return of assets, even if it has become a money-laundering object. The law regulates specific matters functioning as legislation which stand in line with those related to corruption. Basic consideration of this law is the ever increasing private use of the state's funds by private person which is then changed over the ownership through money laundering method. 


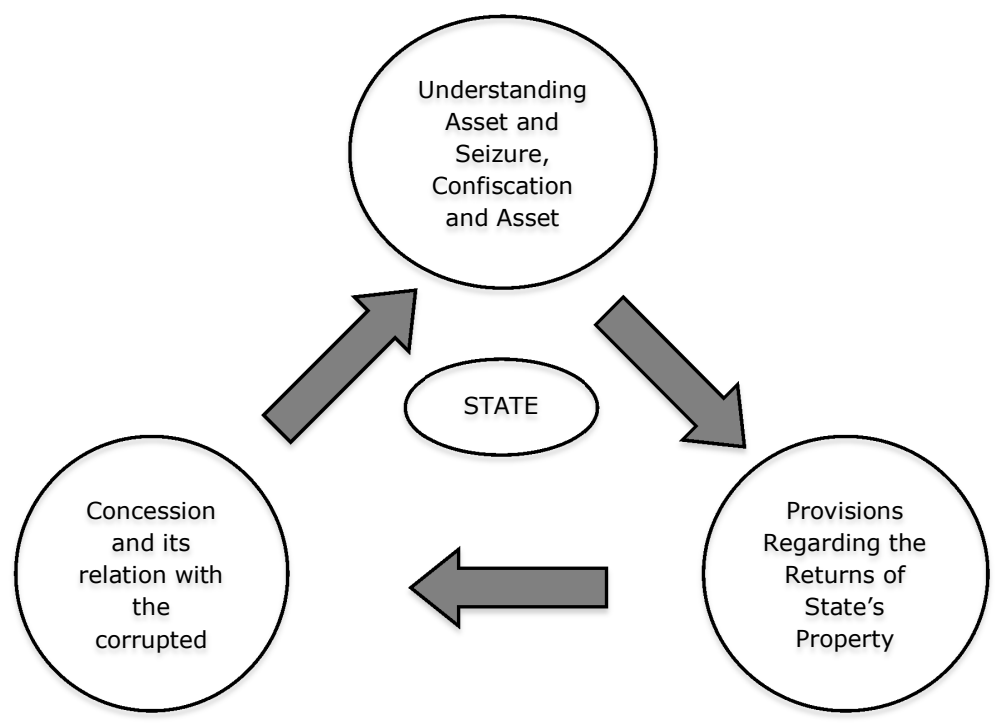

The provisions of this law have also been one of a row of legal regulations which bear the tasks mutually in eliminating corruption.

Arrangement is made not only based on anticipated use of state finances but also based on fact finding of the funds or property. Related investigation of the country's wealth is not absolutely as a distinct wealth which is being renamed but then is solely charged for single crime. Related parties involved in blurring the origin of the funds are then imposed to penalty for money laundering. Related matter included within this law is the regulation in Article 1 of Law No 25 of 2003 where some of the points in question read as follows:

1. Money laundering is the act of placing, transferring, paying, spend, donate, donating, left, brought out of the country, exchange, or other actions on assets known or reasonably suspected to be the proceeds of crime with intent to conceal or disguise the origin of Assets proposal so as to appear to be legitimate assets.

2. Assets are all moving objects or those of immobile nature, both tangible as well as intangible.

3. Suspicious transactions are:

a. Financial transactions that deviate from the profile, characteristics, or customary pattern of transactions of the customer concerned;

b. Financial transactions by customers which are viably suspected of being done to avoid reporting the transaction in question conducted by the Financial Service Provider in association with the provisions of this Act; or

c. Financial transactions undertaken or not completed by using assets which are viably thought to have come from the proceeds of criminal offenses. 
The arrangements in this legislation could then be used as a basis in the understanding that the origin of individual or corporation wealth be the starting point of the implementation of asset returns. In the event of a money laundering case of corruption, multiple penal provisions could be in effect at the implementation stage. Then, the process of asset returns is subdued in other settings related to the return on assets. Another essential things set in this legislation related to eradication of corruption and the return of assets is the implementation investigation on the origins of the laundered money have been conducted independently by the agency for Financial Transaction Reports and Analysis Center (INTRAC) but they do not have the authority to hold a foreclosure, only to the extent of surveillance and prevention. ${ }^{2}$ The action involving the taking or seizure by this law is confirmed by the RI Attorney.

\section{Law 30 of 2002 on Corruption Eradication Commission}

This law is the basis of the establishment of specialized institution known as the handling agent on corruption named the Corruption Eradication Commission, KPK. Structurally, the basic consideration for the establishment of the agency is mentioned that the government agencies that deal with the corruption is still not working effectively. It is obvious that the generic point of the Act No. 30 of 2002 on Corruption Eradication Commission is referring to the authority of this institution over the assets of corruption. Therefore, the concern of this legislation is the authority of anti-corruption agency in relation to the assets or the return of them.

Duties and authority of the Commission is set firmly and clearly denoting that KPK is a specialized institution within the environment of other institutions existing earlier in effort of the corruption eradication. This firmly set authority is used to avoid overlapping authority of existing institutions including those regulating the return o assets. The task of the Commission is set under article 6 of this law, which reads as follows:

\section{Article 6 of the Corruption Eradication Commission has the task: \\ a. Coordination with the authorities to combat corruption; \\ b. Supervision of authorized institutions to combat corruption; \\ c. Conduct investigation, examination and prosecution of corruption; \\ d. Perform preventive measures of corruption, and; \\ e. Perform the monitor of the implementation of state government.}

The task of this institution is not limited as the main organizer of the corruption crime settlement. It is obviously stipulated in the Article 6 point a, indicating the need for a coordination. This arrangement states clearly that the task of the Commission is not concerned formally with the return on assets. It is based on the expectation that in the implementation no overlapping arrangements would be present. The return on assets is rearranged to the main settings of the corruption which formally conducted by the prosecutor. Then, in relation to the authority of the KPK, it has been set down in article 7 of this Law, which reads as follows:

\footnotetext{
${ }^{2}$ Article 26 Act Number 25 of 2003 on Amendment to Act Number 15 of 2002 on Money Laundering Crimes;
} 


\section{Article 7 In carrying out the task of coordination as referred to Article 6 point a, the Corruption Eradication Commission is authorized to:}
a. Coordinate investigation, examination, and prosecution of corruption;
b. Establish reporting system in the activities with regard to eradication of corruption;
c. Inquire information about the activities of the eradication of corruption to the relevant agencies;
d. Conduct hearings or meetings with the authorized agencies in combating corruption; and
e. Request for reports from relevant agencies on the prevention of corruption crimes.

Related to the return of assets, the Commission has the authority in regards to the examination and investigation of wealth as proceeds of corruption. Authority of the Commission related to property or asset is in terms of request to the related agency for wealth and taxation data of the suspects or defendants. ${ }^{3}$ Then, the next setting is the registration and assessment on the wealth reports of the government official concerned. ${ }^{4}$ After an audit report on the property related to corruption crimes, the Commission has the authority to announce the wealth of related party in accordance with the law. The institution is now part of the Corruption Eradication Commission as regulated in the Article 69 of this Law, which reads as follows:

\section{Article 69}

(1) With the establishment of the Corruption Eradication Commission then the State Organizers Wealth Audit Commission, as denoted by the Law Number 28 of 1999 on Corruption, Collusion and Nepotism Free and Clean State Organizers, become part of the Prevention Domain of the Corruption Eradication Commission;

(2) State Operator Wealth Audit Commission as specified in paragraph (1) above shall continue to run the functions, duties, and authority to the accomplishment of Corruption Eradication Commission's duties and responsibilities under this Act.

Based on above explanation, the authorization on the asset return, which fall under KPK authority is limited to financial audit while the formal implementation is not found in this legislation. This is due to the presence of Commission in the pillar of corruption eradication in Indonesia does not negate the other agencies in combating corruption. Moreover, in this legislation, the asset is called as part of the property. Therefore, there is no ambiguity regarding the understanding of the assets or property in the setting of this law.

\section{Law Number 20 Year 2001 regarding Amendment to Law Number 31 Year 1999 on the Eradication of Corruption}

This law was born in a legal securing atmosphere as to strengthen legal setting of Act No. 31 of 1999 on the Eradication of Corruption. Matters governed

\footnotetext{
${ }^{3}$ Article 12 Paragraph (1) point f Act Number 30 of 2002 on Corruption Eradication Commission;

${ }^{4}$ Article 13 Act Number 30 of 2002 on Corruption Eradication Commission;
} 
by this law, some of which are not directly related to the return on assets. The subjects that directly regulate the conduct or return formality of assets were set in the legislation prior to the amendment. The setting on the return of assets in this law as well as in the one prior to the amendment regarding the state asset or property is not explicitly stated on the formality and its implementation. It is solely mentioned as follows:

\section{General Explanation of the Fourth paragraph:}

The concerning financial wealth means the whole country's property in any form, whether set aside or not, including all parts of the country's wealth and all rights and obligations arising from:

a. Being in mastery, stewardship, and accountability of state officials, both at central and regional levels;

b. Being in control, management and accountability of State Owned / Regional Owned Enterprises, foundation, corporation, and the company that includes the state capital, or business firms that include third party capital under contract with the State. While the definition of the State's economy is the economic life organized as a joint venture based on the principle offamiliarity or independent society business which established on government policy's basis, either at central or regional levels in accordance with the provisions of the applicable legislation that aims to provide the benefit, welfare, and prosperity to the entire society's life.

Thus, it is evident that the implementation of the eradication of corruption in Indonesia which is regulated in Law Number 20 of 2001 as an amendment to Law No. 31 of 1999 had not governs the formal aspect of the assets return as well as the scope of the asset. Further legislation is related to the following regulation.

\section{E. Government Regulation Number 65 of 1999 on Implementation Procedures for Examination of State Property}

Government regulations related to the conduct of the state official wealth examination could be associated with the mechanism of the implementation of property inspection. Examination of wealth as intended in this regulation is also associated with fortunes. It was explained in this regulation that the property is those of moving objects, objects of immobile nature as well as other rights owned by the state officials before, during, or after the person concerned takes office. ${ }^{5}$ Based on the understanding, it is clearly revealed that the scope of assets that could be carried out surveillances is as follow:

1. The treasures both mobile as well as immobile objects.

2. Can be other rights which are owned, so it is not limited to material wealth.

There are another properties that could be considered as a fortune which could be of restriction subjects and supervision associated with corruption.

${ }^{5}$ Article 1 General Provisions, Point 4, Government Regulation Number 65 of 1999 on Procedures of State Official Wealth Examination which is an executing regulation of the Law Number 28 of 1999 on Corruption, Collusion and Nepotism Free and Clean State Organizers; 


\section{F. Law Number 17 of 2003 on State Finance, Act No. 1 of 2004 on State Treasury and Government Regulation No. 6 of 2006 on the Management of State / Regional Property in relation to the Scope of Corruption Crimes Results against the State's Treasury.}

Arrangements in the Act No. 17 of 2003 on State Finances are also associated with regulation of the scope of the state finance as part of the material corruption. The state wealth or treasury of the state, if taken not in accordance with applicable laws and regulations which is included in the category of corruption is the wealth of the country which includes:

State finances are all the rights and obligations of the state which can be valued with money and everything in cash as well as goods which could become state property due to the exercise of those rights and obligations. Under the elaboration of state finances as follows:

1. The rights to levy the tax, spend and circulate money, and make loans;

2. The obligations of State to conduct state's duties of public service, the state government and to pay the third party's bills;

3. State Revenue;

4. State Expenditure;

5. Regional Revenue;

6. Regional Expenditures;

7. The wealth of the country / regional assets either self-managed or by others in the form of cash, marketable securities, accounts receivable, goods, and other rights that can be valued in money, including property set aside onto the state / regional companies;

8 The wealth of other parties controlled by the government within the state's governance duties and / or public interest;

9. The wealth of other parties that obtained by using the facilities provided by the government.

Therefore, under these conditions, any action as described in Article 1 paragraph 1 of Law Number 31 of 1999 on the Eradication of Corruption could be categorized as an act of if the corruption is committed affecting the country finance within those scopes above. The understanding of state finances as acknowledged in this law also set limits of the state authority in its management. However, the law does not set or state the mechanism of returning the country's wealth from the corruption offenses. This resulted in the legal status of the property seized, confiscated or frozen whether they entered as part of the property or not.

Then, in the progress, the legislatives had also endorsed a new law namely the Act No. 1 of 2004 on State Treasury. The scope provided for in this law confirms the status of state losses is included in the domain under the authority of this law. Then, in practice, related to Law Number 7 of 2006 regarding Ratification of the United Nations Convention Against Corruption 2003, mentioning that the loss of certain agencies or bodies which are still part of the government administration is the responsibility of the state, including the effect of corruption. Regulation of administration and their implementation in the legislation which then stipulate the arrangement of losses due to corruption 
is included into the state treasury which is subject to the authorization of the Government (Executive) i.e. the Minister of Finance. ${ }^{6}$

The executing regulations of both laws mentioned above are regulated through the Government Regulation Number 6 of 2006 on the Management of State's Property. The scope set out in this Regulation relating to state finances are still the same as the requirements prescribed in the Law Number 17 of 2003 and Law Number 1 of 2004, the above provisions, in its implementation of this regulation is the basis for further management. Discussion on asset recovery under the law or the terms of this provision does not include the return of assets category which, so far has not been expressly mentioned concerning the institution authorized for the returns of corrupted assets and the responsibility for the return of them.

\section{The Understanding of State Finances and the State Asset}

Today's understanding of state finances has become something very important. While the welfare state regime $^{7}$ in power, where the burden of responsibility on people lies with the State, making the definition of state finances is highly required. This creates a distinction between State responsibility and that of irresponsibility of the State. Obligation in question, as expressed by A.J. Wisse in his book is that the Government is obliged to guarantee the lives of decent people to live like a human being. They can live in peace, getting protection on their lives and property, in possession of proper housing, and ability to educate their children in good schools, getting the best possible protection against the attacks of various diseases, ability to eat and get dressed properly, ability for vacation to maintain their health, and so on. ${ }^{8}$

Many experts are already trying to define what the State's finance is. Starting from a simple understanding of who those of complex understanding which has encompassed relating State financial. In the legislation which is the positive law in Indonesia has also been clearly recorded about what is meant by the State finances.

According to Article 1 paragraph 1 of ACT No. 17 of 2003 on State Finance that what is meant by the State Treasury are all the rights and obligations of the state which can be valued with money, and everything in cash or in kind that can be used as state property in connection with the exercise of the right and obligations. ${ }^{9}$

\section{${ }^{6}$ Article 1 General Provision, Point 2, Act Number 1 of 2004 on State Treasury.}

${ }^{7}$ Discourse on the welfare state goes actually linear with the development of the State Role Theory. Departing from the classical Hoobes theory that there is no bond between the state with its people, and then presented by Locke relating state role limits but to assure the rights of individuals who later became the basic foundation of the liberal state / pre-welfare (Night Guard State) until then to a concept of welfare state in which the role of the State be strengthened in terms of fulfilling the rights of its people. Farancis Fukuyama (2005) emphasized this in his book tiled "State-Building: Governance and World Order in the 21 st Century". He said that reducing the state's role concerning matters that are apparently its function will only create new problems. Not only aggravate poverty and social inequality, but also spark social conflict and civil war that asks victims millions of lives. Collapse or weakness of the state has created a variety of humanitarian and human rights catastrophe during the 1990s in Somalia, Haiti, Cambodia, Bosnia, Kosovo, and East Timor (Fukuyama, 2005; see Suharto, 2007)

${ }^{8}$ A.J.Wisse; Keuangan Negara (Yayasan Pembangunan, Jakarta - 1953), p.13.

${ }^{9}$ Article 1, paragraph 1, ACT Number 17 of 2003 on State Finance. 
Substantially, then the State Treasury may be divided into the State Treasury in the narrow sense and in a broad sense. In a broad sense includes the State budget revenues and expenditures, regional budget revenues and expenditures, and those included in the state-owned enterprises / regionally owned enterprises. While in the strict sense, the state finance covers only staterun finances of each legal entity and accounted respectively. ${ }^{10}$

In terms of approach in the formulation of the sense of the financial State can be divided into three, namely:

1. From the object side, the State Finance covers all the State rights and obligation assessable with the money, including policies and activities in the field of fiscal, monetary and management of State Assets which are set aside, and all things, whether in cash or in kind that which could be of the state's possession relating to the implementation of those rights and obligations;

2. Of the subject, which is meant by the financial state is covering the whole object, as mentioned above which are owned by the State, and / or controlled by the central government, regional government, State / regional enterprise, and government agencies related to State finances;

3. Of the process, the State finance covers the entire range of activities related to the management of the aforementioned objects, ranging from policy formulation and decision-making to accountability. ${ }^{11}$

With regards to this matter, many scholars disagree about the meaning and scope of financial state. The first argues that the state finance includes the state budget and all kinds of state-owned capital which originally came from separated state wealth. The other one is of the opinion that the state finances only includes to an extent of those set forth in the Budget. As for the first we could categorize into the State financial understanding in a broad sense and the second as the State financial sense in the strict one.

Prof. A. Hamid S. Attamimi, SH was one of who supports the first argument related to the State finances in the broad sense. It is presented in the book of Prof. Dr. Arifin P. Soeria Atmadja, SH who said that Prof. Attamimi sees under construction in the 1945 section of article 23. Paragraph (1) UUD 1945 (prior to amendment) that determining the state budget should be established by Law, Section (4) specify that the State financial terms should be regulated by law. Clearly the understanding of state budget and state finances needs further investigate whether both are the same or two different subjects because if they are the same thing they should not be regulated in Article 23 paragraph (1) and paragraph (4) 1945 (before amendment) separately. He sees different settings of these two clauses in which subsection (1) defined by Act, while in paragraph (4) it shall be regulated by law. Thereof, it is then concluded that in paragraph (1) the Law is meant to be of formal nature, while paragraph (4) is that of material question beyond formal law. ${ }^{12}$

\footnotetext{
${ }^{10}$ Muhammad Djafar Saidi; .Hukum Keuangan Negara (PT Rajagrafindo: Jakarta, 2008) p.3.

${ }^{11}$ Ibid., p.3.

${ }^{12}$ Prof. Dr. Arifin P. Soeria Atmadja, S.H. Keuangan Publik Dalam Perspektif Hukum. (Badan Penerbit Fakultas Hukum Universitas Indonesia: Jakarta, 2005) p.13.
} 
Then from the explanation of paragraph (5) which states regarding the concrete field of the Government responsibility in the State finance (how to manage the financial spending already approved by the Parliament in order commensurate with the State Budget Law). In reference to Article 23 paragraph (5) 1945 (before amendment) which states that the State's finances, by an explanation, is called the concrete field of the state budget spending, in terms of state finances, as contained in paragraph (4) as well as in paragraph (5), it could be further concluded that meant by the State finance is inclusively the State's Financial Budget. In other words, the state financial terms are including the state's budget and others. ${ }^{13}$

Unlike Prof. Attamimi, Prof. Dr. Arifin P. Soeria Atmadja, SH strongly opposed the expansion of the sense relating to the financial State. Simply to say, Prof. Arifin is for the first opinion which means by the sense relating to the state financial is the state financial budget, so the regional financial budget, state-owned firm's property are not included in the State financial sense. He considered that the terms of State Finance set forth in Law No.17 of 2003 on State Finance Article 2 which adopted the sense of the State finances in the broadest sense. Clearly mentioned in the article that included in the State finances are:

a. The rights to levy the tax, spend and circulate money, and make loans;

b. The obligations of State to conduct state's duties of public service, the state government and to pay the third party's bills;

c. State Revenue;

d. State Expenditure;

e. Regional Revenue;

f. Regional Expenditures;

g. The wealth of the country / regional assets either self-managed or by others in the form of cash, marketable securities, accounts receivable, goods, and other rights that can be valued in money, including property set aside onto the state / regional companies;

h. The wealth of other parties controlled by the government within the state's governance duties and / or public interest;

i. The wealth of other parties that obtained by using the facilities provided by the government.

It is based on an understanding of state finances that is mentioned in article 1, item 1 of the same law namely: all the rights and obligations of the state which can be valued with money and everything in cash as well as goods which could become state property due to the exercise of those rights and obligations. ${ }^{14}$

According Prof. Arifin, the notion of the State finances "offered" by Act No.17 of 2003 is very ambiguous and absurd which even let him give a title to his book "messy Law No.17 of 2003 on State Finances" which discusses in this regard. ${ }^{15}$ He describes how the mix-up occurs between private law and public law in this Act. Clearly the subject related to this mixture is found in Article 2, point I Act No.17 of 2003 which specify that in the State finances is included the property of others obtained by using the facilities provided by the government.

${ }^{13}$ Ibid., p.14.

${ }^{14}$ Article 1, paragraph 1 ACT No.17 of 2003.

${ }^{15}$ Prof Dr. Arifin P. Soeria., Op.cit p.71. 
With this formulation, the State is then responsible for private property receiving facilities from the state ${ }^{16}$ although the facility is in a small amount or minimum. As an illustration, if the private sector is suffering from insolvency and declared bankrupt, it is the obligation of the State to be responsible for the private debt concerned.

It is seen in the case of PT. Karaha Bodas where Pertamina was claimed to pay damages of U.S. \$ 261 million by the KBC on the development project of Geothermal Power Plant (PLTP) on Energy Sales Contract (ESC) of which one of the project was delayed by the Government will potentially has to bear all the losses suffered by the company, including 95\% of Government-owned money in the bank in the United States. ${ }^{17}$

Clearly this is a loss, due to the State financial arrangements contained in the Act No.17 of 2003 hence the State should bear the loss that it should not. This situation will get worse if in the same condition several private companies have the same state of insolvency which led to a cumulative loss of state finances. This would certainly not going to happen if there is a strict distinction between private and public law and strict regulation about what constitutes the State finances.

Even in Indonesia the definition of the State finances could be understood on three interpretations of Article 23 UUD 1945 (pre amendment) which is the constitutional foundation for state finances. ${ }^{18}$ The first interpretation is:

“... The State financial sense is interpreted narrowly, and it may be mentioned as the State finance in the narrow sense, that covers only the State finances, which originated from the state budget, as a subsystem of a state financial system in the strict sense." 19

If it is based on the formula, then the State finances are all aspects covered in the budget proposed by the government to Parliament each year. In other words, the state budget is a description of the State finance, so the supervision on the state budget is also the financial supervision upon the State. ${ }^{20}$

The second interpretation is related to the systematic and historical method, which states:

"... The State finance in the broadest sense, which includes financial state originated from the state budget, regional budget, State-owned Enterprises, Regional-owned enterprises, and essentially all assets of the State, as a state financial system ..."21

\footnotetext{
${ }^{16}$ Ibid.,p.75.
}

${ }^{17}$ Ibid.,p.75.

${ }^{18}$ Rochmat Soemitro. "Tanggung Jawab Keuangan Negara." Padjajaran 2 (April-June,: 1981) p..4 in Safri Nugrahaet al.. Hukum Administrasi Negara. (CLGS Fakultas Hukum Universitas Indonesia: Depok, 2007) p.329.

${ }^{19}$ Arifin P. Soeria Atmadja, "Reorientasi Penertiban Fungsi lembaga Pengawasan dan Pemeriksaan Keuangan Negara," (Inauguration speech as an Extraordinary Professor in the Faculty of Law University of Indonesia, 21 June 1997), p..8 in Safri Nugraha et al. Hukum Administrasi Negara. (CLGS Fakultas Hukum Universitas Indonesia: Depok, 2007) p.329.

${ }^{20}$ Safri Nugraha Dkk. Hukum Administrasi Negara. (CLGS Fakultas Hukum Universitas Indonesia :Depok, 2007) p.329.

${ }^{21}$ Atmadja, op.cit., p.8 in Safri Nugraha et al. Hukum Administrasi Negara. (CLGS Fakultas Hukum Universitas Indonesia :Depok, 2007) p.330. 
The significance of this second interpretation is that the state financial is all things related activities closely related with the money that was established by the State for public interests. In essence the State finance is the same as State assets which consists of:

"... The assets and liabilities, all the goods that have value for money, such as land, rivers, mines, mountains, within the territory of the Republic of Indonesia as well as all facilities owned by State, both derived from the purchase or acquisition of other ways." 22

The third approach is performed through a "systematic and teleological or sociological approach to the financial state that can provide relatively more accurate interpretation in line with intended purpose". ${ }^{23}$ The point is:

"If the purpose of interpreting the State finances is intended to determine the management and accountability systems, the notion that State finances is tight. Further on the State financial terms, if the approach made by using a systematic and teleological interpretation, the notion of the state finances is that of the financial broad sense, i.e. including finances which are in the state budget, regional budget, state-owned and regional-owned enterprises and all the state wealth are essentially the object of inspection and supervision."24

Of these three interpretations, the third one seems the most essential and dynamic in responding to developments existing in the society. ${ }^{25}$ This third interpretation is also coherent with the view that the state finance understanding comprises of two constructions, the first construction that states finance as referred to Article 23 paragraph (1) and paragraph (5) 1945 (pre-amendment), which includes solely the financial budget. ${ }^{26}$ The second construction states:

"State financial which accountability examination on the implementation is of the Financial Audit Agency (BPK) duties and the audit results are notified to the House is not only covering the Budget set each year by law but also includes a separated budget, either set apart to local government, the state-owned, regional-owned enterprises as well as to other agencies."

\section{The Understanding of State Assets}

Asset is a familiar term particularly for the economic intellectuals. This word can be described as an everyday word used, discussed and learned in classrooms and economic discussion groups. What is really meant by asset? The subject will be answered in this section.

${ }^{22}$ Soemitro, op.cit., p.8 in Safri Nugraha et al. Hukum Administrasi Negara. (CLGS Fakultas Hukum Universitas Indonesia :Depok, 2007) p.330.

${ }^{23}$ Atmadja, op.cit., Hal.8 dalam Safri Nugraha Dkk. Hukum Administrasi Negara. (CLGS Fakultas Hukum Universitas Indonesia :Depok, 2007) p. 331.

${ }^{24}$ Ibid.

${ }^{25}$ Safri Nugraha Dkk. Hukum Administrasi Negara. (CLGS Fakultas Hukum Universitas Indonesia :Depok, 2007) p. 331.

${ }^{26}$ Presented by A.Hamid Attamimi in his book Keuangan Negara Lingkup Pengertiannya dan Hakekat Perundang-undangannya Menurut UUD 1945, adapted in the book of Financial Audit Agency, op.cit., hal.30. 
According to the Dictionary of Economics written by Drs. A. Nasution et al, Asset is defined as:

Terms of book keeping. At the balance sheet (of a company, what company have and value for money that is classified as property (asset), the overall amount of property equal to the debts (liabilities). Treasures belong to these categories, at random in order elongated and declare the value of their money that will separate the company's business (a) Current assets: cash, bank deposits and the details that may be expressly restored to cash, bill acceptable, inventory (stock) and result of increased deposits, marketable goods (b). Trade Investment (capital investment or trade): capital that supports the company or companies associated with (c). Fixed assets: Land, buildings, plant and machinery, vehicles and office equipment; depreciation which is usually reduced. (d). Intangible assets (unexpected treasure): services, patent, etc. Individual treasure is the property or debts of another person who has a positive value for money. ${ }^{27}$

According to the Financial Accounting Standards Board (FASB) definition of asset is as follows (SFAC No. 6, paragraph 25):

"Assets are probable future economic benefits obtained or controlled by a particular entity as a result of past transactions or events"

With the same meaning, IASC defines assets as follows:

"An assets is resource controlled by the enterprise as a result of past events and from which future economic benefits are expected to flow to the enterprise"

In the Statement of Accounting Concepts No. 4, Australian Accounting Standards Board (AASB) defines an asset as follows:

"Assets are service potential or future economic benefits controlled by the reporting entity as a result of past transaction or other past events"

FASB and AASB definition is quite broad compared to the other definitions for asset is assessed as having the nature of the economic benefits and not as an economic resource since the economic benefits do not restrict the form or type of economic resources that can be included as an asset.

Based on the above description, it could basically be concluded that there are three main characteristics that must be met for an object or the post to be called an asset, namely:

1. The future economic benefits is quite definite

To be referred to as an asset, an object must contain in the future economic benefits which are sufficiently certain. Money or cash has benefits or services potential because of its purchasing power or the power of its exchange. Sources other than cash has economic benefits because it can be exchanged for cash, goods, or services, as it can be used to produce goods and services, or because it can be used to pay off liabilities.

${ }^{27}$ A. Nasution et al.; Kamus Ekonomi. Dahara Prize: Semarang, 1989) p.19-20. 


\section{Mastered or controlled by entities}

To be referred to as an asset, an object or post should not necessarily be owned by entities, but simply being controlled by the entity. Accordingly, the concept of mastery or control is more important than the concept of ownership. By mastery, here means the ability of the entity to obtain, maintain / hold, exchange, and using economic benefits and preventing the access of others to those benefits. It is based on the basic concept of "substance over form". Ownership has only a juridical or legal significance.

\section{Arising from past transactions}

This criterion actually perfects the mastery criteria and at once as first criteria or tests (first-test) of object recognition as an asset. Assets should arise as a result of past transactions or events are the criteria to meet the definition. Mastery shall be preceded by a transaction or economic event. FASB put the transaction or occurrence as the criteria of asset since that transactions or events could lead to add or exclude (decrease) in assets. For example, changes in interest rates, depreciation or accident.

FASB identified five meanings or attributes that could be represented regarding with the asset, the basis of assessments by the FASB (SFAC No.. 5, prg. 67) could be summarized as follows:

a. Historical cost. Land, buildings, fixtures, factory equipment, and most stocks are reported on the basis of the historical cost, namely cash or its equivalent amount of money that were sacrificed to obtain it. Historical costs are certainly adjusted by the number of depreciated or amortized parts.

b. Current (replacement) cost. Some preparations are submitted at present value or the replacement, namely the amount of money or its equivalent that must be sacrificed if certain assets acquired presently.

c. Current market value. Several types of investments in marketable securities are presented on the basis of current market value namely the amount of money or its equivalent that could be obtained by business entity from selling the assets in normal condition of the company (not under liquidation). The current market value is also used for assets that are likely saleable at any price lower than book value.

d. Net realizable value. Several types of short-term receivables and inventory items are presented at net realized value namely an amount of cash money or its equivalent that will be accepted (undiscounted) from the asset deducted by the sacrificed cost needed to convert the assets into cash or its equivalent.

e. Present (or discounted) value of future cash flows. Long-term receivables and investments are presented at the present value of future cash receipts to the settlement of the outstanding accounts receivable (at implicit discount rate), minus the additional costs which may be required to gain the receivable concerned.

The above are definitions of assets from economic point of view, then the understanding from legal scientific sense, basically there is no precise definition of what is meant by asset in understanding, both either we open the legislation or observe the opinions of experts. But in the legal science, there are 
terms known as Property of the State's Treasury (BMKN) or the State's Property (BMN), which appears in the Government Regulation No. 2 of 2001 on Security and Transfer of State Property from The Central Government to The Regional Government in the Framework of Regional Autonomy Implementation.

In the Ministry of Finance (PMK) Regulation No.71/PMK.06/2006 On Removal Procedure of State Property caused by Earthquake in Yogyakarta Special Region and Central Java Province Article 1 paragraph 2 is described by the State Property (BMN) means the State Property, hereinafter referred to as $\mathrm{BMN}$, are all items purchased or obtained at the expense of State Budget (APBN) or from other lawful acquisition. ${ }^{28}$

In Article 1 paragraph 1 Government Regulation \#2, 2001 explained that the definition of Property/Treasures of State, hereinafter referred to BM/ KN include movable/immovable goods owned/controlled by the government agencies that are partly or wholly purchased at the expense of the state budget or by other lawful acquisition, which exclude the separated state property (managed by state-Owned Enterprises) and the wealth of local government. ${ }^{29}$

From the description of Article 1 paragraph 1 it could be decomposed into several important elements, namely:

\section{Moveable or immovable goods.}

Prof. Subekti SH explained that the definition of a moving object is divided into two, namely moving good which is due to its nature and moving objects as defined by the Act. Moving object by its nature are those which are not affiliated with land or intended as attachment to land or buildings such as furniture items. $^{30}$ Moving objects as defined by the Act e.g. life rent of moving object or annuity, collection of money or a moving object, stocks and bonds. ${ }^{31}$

While the definition of the immobile object divided into three including immobile by its nature, immobile due to its use, and those as determined by law. The immovable objects by the nature of the soil including everything that directly or indirectly due to natural or man-made actions are closely united together with the land. ${ }^{32}$

Immobile objects due to the purpose of the use is anything that seriously though coupled with the land or building, intended to follow the land or building for a long time, for example, the machines in a factory. ${ }^{33}$ Further immovable objects as defined by the Act are any rights or collection of an immovable object such as annuity of an immovable object, easement, postal rights, leasehold rights and billing rights to return or hand over the immovable object. ${ }^{34}$

${ }^{28}$ Miniater of Finance Regulation (PMK) No.71/PMK.06/2006 on Removal Procedure of State Property caused by Erthquake In Yogyakarta Special Region And Central Java Province, Article 1 paragraph 2.

${ }^{29}$ Government Regulation No.2 of 2001 On Security and Transfer of State Property/Treasures From The Cntral Government to the Regional Government In the Framework of Regional Otonomy Implementation, Article 1, Paragraph 1.

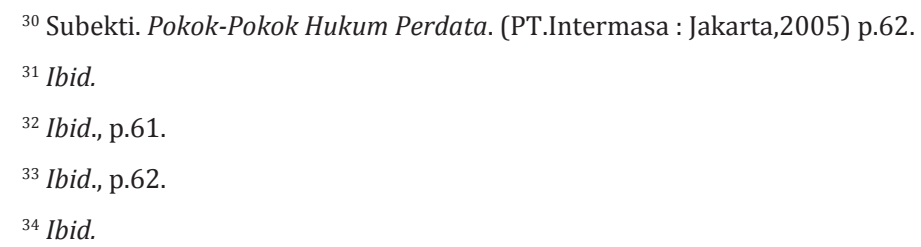


We can see that the categorization of assets issued by FSAB above (Historical Cost, Current / Replacement Cost, Current Market Value, Net realizable value, and the Present (or discounted) value of future cash flows) are the four categorizes which could be classified among the movable or immovable chattels.

2. Owned / controlled by Government Agencies

The second element is also in accordance with the characteristics mentioned by FSAB which is an asset to be possessed / controlled by the entity. Since, in this case, we are talking about state asset then the entity in question is surely a government entity which in this case is representing the State.

3. Partially or wholly purchased at the expense of State Budget / other Legitimate acquisition

The third element is also in accordance with the characteristics of assets issued by FSAB which define the asset must arise from past transactions.

4. Exceptions are the State's separated property and the wealth of regional government.

Based on the elaboration of the elements of BMKN above, it could be seen that what is meant by BMKN could be equated with the elements and the meaning or definition of assets issued by FSAB. So that we can say regarding what is meant by that State assets are State Property / Treasures.

\section{Scope of State Assets in perspective}

In the previous sub-chapter, it was explained about what has been meant by an asset, BMKN and State asset. This section will explain about the scope of State assets in a legal perspective which means the limitations of the State assets in the scope of law.

Starting from the explanation of State Property / Treasures (BMKN) Article 1 Paragraph 1 of Government Regulation No. 2 of 2001 on Security and Transfer of State Property / Treasures from the Central Government to the Regional Government in the Frameworks of Regional Autonomy Implementation, which is meant by BMKN is movable / immovable property owned / controlled by the government agencies that are partly or wholly purchased at the expense of State Budget or other lawful acquisition, which does not include separated state property (managed State Owned Enterprises) and the wealth of regional government. ${ }^{35}$

From the article linked with BMKN above we can see a definitive scope BMKN is: moving / immovable objects controlled / owned by the government of which the acquisition is at the expense of the state budget or other lawful acquisition, except the separated state property (managed by State-Owned Enterprises) and the wealth of regional government. Based on the elements of Article 1 paragraph 1 PP 2 of 2001, BMKN does not include the separated state

${ }^{35}$ Government Regulation No.2 of 2001 On Security and Transfer of State Property/Treasures From The Cntral Government to the Regional Government In the Framework of Regional Otonomy Implementation, Article 1, Paragraph 1. 
wealth and local government property. It is interesting, because the definition of the State Finance section can be seen the disagreement on the scope of a State finance itself. But the PP is confirmed if BMKN is limited to the extent of wealth which is solely "in hands" of the central government.

In the PP 6 of 2006 on the management of State / Regional Property it is quite clear about what is meant by the State Goods. State property is all goods purchased or obtained at the expense of the state budget or from other lawful acquisition. ${ }^{36}$ In chapter 2 the same PP paragraph it is further explained about the elements of State Property:

(1) Goods of state / regional property include:

a. goods purchased or obtained at the expense of State/Regional Budget;

b. goods originating from other lawful acquisition;

(2) Goods referred to paragraph (1) point b include:

a. goods obtained from grants / donations or the like;

b. goods obtained as the implementation of the agreement / contract;

c. goods obtained under the provisions of law; or

d. goods obtained based on court decisions that have permanent legal force. ${ }^{37}$

From the Article: 2 PP 6 of 2006 can be concluded that BMKN are goods obtained from grant / donation or the like ${ }^{38}$, goods resulting from the implementation of the contracted agreement, goods from the provision of Act, and the goods due to court decisions that have fixed legal force.

From the Article 2 above the law imposes limitation or scope of what we refer to as BMKN, where it consists of four types of goods as mentioned above. All provide general restriction against BMKN, while the specific restriction is specified in the agreements / contracts governing the point b and Special Act governing further point c, such as the Customs Act. ${ }^{39}$

In the Act No.1 of 2004 on State Treasury, which is the highest legal umbrella of the State Financial Administration, is also mentioning several types of goods that is in the regulation scope of Law No.1 of 2004 namely Money, Debt, Receivables, Investments, and the Goods of the State / Region property. ${ }^{40}$ This law directly imposes limitation that what are stipulated in the Financial Administration by this Act is limited to the five kinds of the State wealth (i.e. Money, Debt, Receivables, Investments and State / Regional Property).

\section{Mastering the right of the State assets}

State-related study is something which is closely related to the legal science, in which almost every part the State has always been the object of legal science. Either by Criminal, Civil, Constitutional, Public Administration or International Law they all make the country as one of the science object. It

${ }^{36}$ Government Regulation No.6 of 2006 On Management of State/Regional Property, Article 1, Paragraph 1.

${ }^{37}$ Ibid., Article 2.

${ }^{38}$ In the explanation is described that it includes the Contract of Work, Production Sharing Contract, Utilization Cooperation Contract.

${ }^{39}$ In the explanation example is given in terms of the Customs Act, including in this definition is the State's assets acquired from foreign / China and so on.

${ }^{40}$ ACT No.1 Of 2004 On The State Treasury. 
becomes something that cannot be avoided when we study the science of law. ${ }^{41}$

The following are some expert opinions about the meaning of the State:

a. According to Roger H. Soltau, the state is an agency or authority managing or controlling these common affairs on behalf of and in the name of the community.

b. Harold J. Laski defines: The state is society which is integrated by processing a coercive authority legally supreme over any individual or group which is a part of the society. A society is a group of human beings living together and working together for the satisfaction of their mutual wants. Such a society is a state when the way of life to which both individuals and associations must conform is defined by a coercive authority binding upon them all.

c. Definition by Robert M. Mac Iver: The state is an association which, acting through law as promulgated by a government endowed to this end with coercive power. Maintains within a community territorially demarcated the external condition of order.

Thus the concept of the State, that the State is a territory whose people governed by a number of officials who managed the citizens keeping the legislation through monopolistic control by the legitimate power. ${ }^{42}$ And several other experts provide minimum standards for an entity to be called a State, that the entity has at least three main elements, namely: (1). People or a number of people (2). Certain area and (3). Government and sovereign authority, and as complementary elements which could be added is the recognition of the international community or other countries. ${ }^{43}$

Hans Kelsen gives understanding of the State from various country structure points of view as: (a) The personification of the National Legal Order, (b) Legal Order and the Community established by the legal order; (c) The State as a sociological entity, (d) The State as an organization of political society (the State as a ruler). ${ }^{44}$

State as a personification of the National Legal Order, by Kelsen is based on the theory of legal pure science namely the state is only seen as a legal phenomenon, as a legal entity, as a corporation. That way, the nature of the state is determined by the definition of the corporation. State as a legal entity is a personification of the national legal order which form the community. Therefore, he also observes from a legal perspective, the question of the State appears as a matter of national legal order. State as a legal order and the community formed by the legal order, that the State as a legal community is an integral entity with legal order. The state is the legal order. ${ }^{45}$

State as a sociological entity, not merely as a legal reality, but sociological reality, namely the social reality that is untied off legal order, only if it could be proved that the individuals who make up a whole country form a unity and that

${ }^{41}$ Miriam Budiarjo, Dasar-Dasar Ilmu Politik (Jakarta : PT. Gramedia, 2003), hlm. 141.

${ }^{42}$ Ibid.

${ }^{43}$ Muhammad Tahir Azhary. Negara Hukum: Suatu Studi Tentang Prinsip-Prinsipnya Dilihat dari Segi Hukum Islam, Impelementasinya Pada Periode Negara Madinah dan Masa Kini. (Jakarta: Kencana Prenada Media Group, 2007) p.17.

${ }^{44}$ Hans Kelsen, General Theory of Law and State, See as well in Raise Muttaqien, Teori Umum tentang Hukum dan Negara, (Bandung : Nusa Media \& Nuansa, 2006), pp. 261- 275.

${ }^{4}$ Ibid. 
the unity is not created by the legal order but by the elements not related to the law. ${ }^{46}$

State as a political organization (power) is explaining that the State is political establishment. Country is a politically organized society because the state is a community formed by a coercive order, and order that is forcing this is the law. The concept of state power can be defined as an organization set up by the legal order. In Indonesia, this understanding can be interpreted as the legislative, executive and judicial as power organization and the power organization is formed by the legislation. State as a power organization set up by the legal order as stated by Kelsen, then the founding of the state is at the same time as the establishment of legal order. In regard to the time of the founding of the State of Indonesia, the independence proclamation of Indonesia is the first norm of the Indonesian legal system. ${ }^{47}$

From a philosophical perspective, many experts have suggested regarding countries and establishment of the State, one of whom was an English philosopher named Thomas Hobbes $^{48}$, who gave the initial illustration on formation of a State, where it begins with a situation which he named "Natural State". ${ }^{49}$ Scientific state is a hypothetical concept that is a concept which is purely a product engineered by Thomas Hobbes. The concept, which certainly of an engineering effort departs from Hobbes imagination, he in himself has no historical foundation for a theory. He used the term "Scientific State" which gives you an idea (to borrow a Weberian terms) namely the ideal type of human society before merging into political society..$^{50}$

In Hobbes's opinion, that in the state of nature, man is a ruthless creature, which amongst them will prey on each other. From this then arises competition among human beings. Who wins will survive and be powerful, while the loser would be eliminated. Due to the urge to survive, human then attempt to utilize efficiently all the capabilities and resources he has including the power to keep surviving. This results then in human life being marred always by violence, competition and conflicts of power. From here he went on to the term "homo homini lupus" where humans will fight against other human beings.

Also in the state of nature the political and social structures of power has not been established. Humans are still free to do what he wants as demanded by his instincts. ${ }^{51}$ For instant, somebody wants to kill somebody else, he then will easily go and kill another human being without fear of dealing with the legal sanction or social sanction that emerged in the community. At this stage the term law is something unfamiliar to human. It was the deadlock in the state of nature which then pushed the human mind to create a solution in which each

\section{${ }^{46}$ Ibid.}

${ }^{47}$ Juniarto, Sejarah Ketatanegaraan Republik Indonesia (Jakarta : Bumi Aksara, 2001), pp.5-6.

${ }^{48}$ Hobbes was born in poor families. His father was a preacher, sent Hobbes to his rich uncle. His uncle raised and educated Hobbes. At his uncle expenses Hobbes studied at Oxford University. In Oxford, Hobbes studied Aristotle whom later on he criticized. (Quoted from Western Political Thought by Ahmad Suhelmi p.166).

${ }^{49}$ Or in other language is named State of Nature.

${ }^{50}$ Ahmad Suhelmi. Pemikiran Politik Barat: Kajian Sejarah Perkembangan Pemikiran Negara, Masyarakat dan Kekuasaan. (PT Gramedia Pustaka Utama: Jakarta, 2001); p. 175.

${ }^{51}$ Ibid. 
human being could live in peace and prosperity. Departing from this point the man then started to move to the next stage where people began to develop what is named political community.

In political society, there starts to form social structures in which the desire to establish a state that can guarantee the rights of every human being can be realized. With the guidance of human logical reasoning 52 then a joint force is established in order to avoid bloodshed. The joint force is then realized in the form of social covenant ${ }^{53}$ to form a State.

This social contract binds individuals to each other, not between individuals with the State. The country itself is above the individual, this has resulted in the State itself is free from the bound of the agreement. ${ }^{54}$ As a result of this, the State plays a source of truth, the power source which at the same time is the source of law for individuals who live in it. Logic state is absolute. There should be no rebuttal or refutation. According to Hobbes it is necessary in order to reconcile the natural conditions of the previous case, the State should be transformed into a State of authority (machtstaat) that in possession of character such as Leviathan powerful, ruthless, and the respected State. Absolute Monarchy State is the most appropriate form where there is no Political Pluralism; it is to defuse the conflict of power. State under one ruler would be better than the State, led by a board, because the State with single ruler will be more stable and policies will not be easily changed. ${ }^{55}$

Of logic and the theory developed by Hobbes it could be seen that the State has absolute power, and each individual must submit to her. It results then in the impact on one of the rights owned by the State namely the Rights to master the State.

The rights of Mastering the State is well known in the concept of mastering the Land Law which in article 2, paragraph (1), (2), and (3) Law No. 5 Year 1960 concerning the Basic Agrarian is stipulated that:

(1) On the basis of the provisions in Article 33 paragraph (3) of the Constitution and matters referred to in Article 1, earth, water and airspace, including the natural resources contained therein is at the highest levels controlled by the State, as the power organization of the entire people.

(2) The mastery of the State referred to in paragraph (1) of this section gives the authority to:

a. arrange and conduct the allocation, use, inventory and maintenance of earth, air and aerospace;

b. determine and regulate the legal relationships between people with earth, water and air,

${ }^{52}$ In Hobbes' opinion human logical reasoning push them to live peacefully.

53 The term used by Hobbes to name the social treaty to establish a state.

${ }^{54}$ Suhelmi. Op.cit., p. 176.

${ }^{55}$ We can see the practice in Indonesia during Pre-Reformation period, in which the state power is positioned in one hand i.e. the President. Both Soekarno and Suharto had absolute power. Soekarno for example by his power he made himself the center of power and politics in which he named the concept a guided democracy. Meanwhile, Suharto in his own way during the New Order era had made Indonesia an authoritarian state with himself as the center of power and politics. 
c. define and regulate the legal relationships between persons and legal actions on earth, water and airspace.

(3) The authority which comes from the the State right of control referred to in paragraph (2) of this section is used to achieve the maximum benefit of the people, in the sense of happiness, prosperity and freedom in society and the State of Indonesia which is independent, legally sovereign, just and prosperous $^{56}$.

Of exposure in article 2, paragraph 1-3 Act No.5 of 1960 we can take the conclusion that the State as the organ of the people sovereignty embodiment and the interests of entire people has the full sovereignty of the State property. In this case the State has the right to control the State, where the points relating to the State's mastery rights are summarized in article 2, paragraph (2) Law No. 5 of 1960. But surely the consequences of this is the right objectives attaching the State rights to control is to create the greatest possible prosperity of the people, in the sense of happiness, prosperity and freedom in society and the State of Indonesia which is independent, legally sovereign, just and prosperous. It is considered highly logical given only State that could be attached with authority to represent the interests of all communities in that State. A prominent figure by the name Muhammad Yamin interprets words "Controlled by the State" in the provisions of Article 33 paragraph (3) Act 1945 is in the sense that the highest authority in a country are of the sovereignty of the people. Thus the highest power can only live in the hands of the people or the sovereign state.

As in theory of representation, the state's presence is considered representing the general will, namely the will which depart from the votes of majority people regarding how the country is managed. According to Jean Jacques Rousseau whose opinion says that the general will is always right and never wrong ${ }^{57}$, so it is natural if then the State will be given more than individuals. This is to actualize the general will delegated by the people either through the general election or referendum process as is usually the case.

The application of the State Right to Control depends on the sociopolitical and cultural conditions of the communities in the State in question. In simple terms it can be seen that with the State rights to control the State is legally entitled at the reason for public interests to take over private property rights. This is because the interest and the public will have a higher position than the private interests. General conception related with the State rights to control is just like inji, only its application is different in communist / socialist / Marxist ideology State to those of liberal ideology. At the State of postcommunist ideology the takeover of individual property rights is done without any reimbursement or compensation given by the State to private person / individual concerned. This is because the public rights eliminate the individual rights, because it is considered that the removal of individual rights in order to create public (communal) rights which will then be returned to the individual in terms of public facility or service.

While in the liberal state, where individual rights are highly respected, the efforts of the State to do the hegemony of an individual property will in return be rewarded in form of a compensation payment in amount of reasonable value

${ }^{56}$ ACT. No.5 of 1960 On Basic Regulations of Agrarian Principles, Article 2.

${ }^{57}$ Jean Jacques Rosseau. Perihal Kontrak Sosial. (Dian Rakyat: Jakarta,2010) Hal.35. 
corresponding with the individual rights acquired by the State. So in this case even though the State has the rights to control but the context of State mastery is as far an extent as the formal one where material wise the individual right is remained honored.

State assets as a form of State treasures, which is formulated as in Article 33 UUD 1945, shall be controlled by the State. It is a form of custody of the State over the public interest in order their rights would not be deprived by the liberal market mechanism so that the prosperity ideally wished by our founding fathers could be favorably achieved.

The hands of the State may be able to contribute actively on how then any kind of asset and the existing potentials could be maintained and used as much as possible for the prosperity of the people. It is fully the responsibility of the State as holder of a full mandate of the people. And as the only principal organ that could represent the public in policy takings.

\section{A. Public rights and private rights of state asset management}

What is by the Public Right and Private Rights, of course, some of us have often heard in this respect, particularly we who are active in the academic world of law both as professors and students, or in the world of practices such as attorneys and judges. There has always been a distinction between public and private ownership, between what is meant by the public's right and what is meant by private rights. In a matter of law we also recognize the distinction between public law and private law.

Simply to say, public law is often defined as the law governing the relationship between societies and state, while private law is often defined as the law governing the relationship between one individual with another in a State. An example of public law is criminal law and civil law is an example of private law.

In the context of public law the State acts as guarantor of the rights of other citizens, which in case of violation the state shall be obliged to try and provide a form of punishment for citizens who committed offenses. This is done as a form of State responsibility to meet the individual rights which exist in the community. While in private law, the context of the State is more likely an arbitrator. Where in the private law individuals are dealing with other individuals in solving problems, even if there are countries that are dealing with individuals in private legal conflict resolution, then at the time the state will have no public immunity, because of its position is the same as the position of other individual / State citizen. ${ }^{58}$ It is subject to the applicable private law and not to public law.

\section{Conclusion}

Among the regulations, we had to know that eradication assets must be retracted. State, along with righteous organizations, as the main frontier of enforceable action, shall be given their own jurisdiction in order to comply the

\footnotetext{
${ }^{58}$ A state's national is a citizen of a country defined by legislation (Act 12 of 2006 on Citizenship of the Republic of Indonesia, Article 1 Paragraph 1);
} 
law. Also, the State may be able to contribute actively on how then any kind of asset and existing potentials that already retracted, could be maintained, protected and used as much as possible for the prosperity of the people. Inded, it is the responsibility of the State as a mandatory-power holder of indonesian citizen.

\section{Bibliography}

\section{Books}

A. Nasution Dkk, 1989. Kamus Ekonomi. Semarang : Dahara Prize.

Azhary, Muhammad Tahir, 2007. Negara Hukum: Suatu Studi Tentang PrinsipPrinsipnya Dilihat dari Segi Hukum Islam, Impelementasinya Pada Periode Negara Madinah dan Masa Kini. Jakarta: Kencana Prenada Media Group.

Budiarjo, Miriam, 2003. Dasar-Dasar Ilmu Politik. Jakarta : PT. Gramedia.

Juniarto, 2001. Sejarah Ketatanegaraan Republik Indonesia. Jakarta : Bumi Aksara.

Kelsen, Hans, 2006. General Theory of Law and State Lihat juga dalam Raise Muttaqien, Teori Umum tentang Hukum dan Negara. Bandung : Nusa Media \& Nuansa.

Prof. Dr. Arifin P. Soeria Atmadja, S.H. 2005. Keuangan Publik Dalam Perspektif Hukum. Jakarta : Badan Penerbit Fakultas Hukum Universitas Indonesia.

Rosseau, Jean Jacques, 2010. Perihal Kontrak Sosial. Jakarta : Dian Rakyat.

Safri Nugraha Dkk. 2007. Hukum Administrasi Negara. Depok : CLGS Fakultas Hukum Universitas Indonesia.

Saidi, Muhammad Djafar, 2008. Hukum Keuangan Negara. Jakarta : PT Rajagrafindo.

Subekti. 2005. Pokok-Pokok Hukum Perdata. Jakarta : PT.Intermasa.

Suhelmi, Ahmad, 2001. Pemikiran Politik Barat: Kajian Sejarah Perkembangan Pemikiran Negara, Masyarakat dan Kekuasaan. Jakarta : PT Gramedia Pustaka Utama.

Wisse, A. J, 1953. Keuangan Negara. Jakarta : Yayasan Pembangunan.

\section{Legislations}

- Law Number 5 Of 1960 On Basic Regulations Of Agrarian Principles;

- Law Number 30 of 2002 On Corruption Crime Eradication Commission;

- Law Number 25 of 2003 Amendment of ACT Number 15 Of 2002 On Money Laundering Crimes;

- Law Number 17 Of 2003 On The State Finance;

- Law Number 1 Of 2004 On The State Treasury;

- Law Number 12 of 2006 On Citizenship of the Republic of Indonesia;

- Government Regulation Number 65 Of 1999 On Procedure of Inspection on the Wealth of the State Executives As Implementation Regulation of ACT Number 28 of 1999 On the Clean and Corruption, Collusion and Nepotism Free State Executive; 
$\sim 280 \sim$

- Government Regulation Number 2 Of 2001 On Securing and Transfering Goods of the State Property/Wealth From the Central Government to the Regional Government in the Framework of the Regional Autonomy Implementation;

- Government Regulation Number 6 Of 2006 On the Management of the State/ Regional Property;

- Minister of Finance Regulation (PMK) Number 71/PMK.06/2006 On the Procedure of Abolition of the State's Property as Result of Earthquake In Special Region of Yogyakarta and Central Java Province; 